\title{
Respon Pertumbuhan Bibit Salak (Salacca Zallaca) terhadap Dosis Spora Endomikoriza pada Media Pembawa Pasir Kuarsa dan Zeolit
}

\author{
NI KADEK ARYANI, I NYOMAN RAI*), DAN NI NYOMAN ARI MAYADEWI
}

Program Studi Agroekoteknologi Fakultas Pertanian Universitas Udayana

J1. PB. Sudirman, Denpasar 80231 Bali

${ }^{*}$ E-mail: rainyoman@unud.ac.id

\begin{abstract}
Response of Salak Seedlings (Salacca Zallaca) Growth to Dosage of Endomycorrhizal Spore in Quartz Sand and Zeolite Carrier Media. This study aimed to study the effect of endomycorrhizal spore dosage and carrier media that were applied directly to the roots of salak plants. The research designed as factorisl by using Randomized Block Design with 2 treatment factors. The first factor was number of endomycorrhiza spores consists of 4 levels i.e $0,75,150$, and 225 spores per $500 \mathrm{~g}$ carrier media per polybag, while the second factor was the type of carrier media consist of 2 levels i.e zeolite and quartz sand. The results showed that interaction between endomycorrhizal spore dosage with carrier media did not significantly influence the growth of salak seedlings. Endomycorrhizal spores in doses of 75, 150 and 225 spores per polybag increased root infection and leaf $\mathrm{P}$ nutrient content compared to control, but seed height, leaf area, shoot dry weight, root dry weight and total dry weight of seedlings not significantly difference. The zeolite carrier media caused root infection by mycorrhizal was higher than quartz sand media, but the $\mathrm{P}$ nutrient uptake and seedling growth were not significantly different. Based on the results of this study it is necessary to make a longer observation of the effect of endomycorrhizal spore doses and carrier media on the growth of salak seedlings.
\end{abstract}

Keywords: mycorrhizal, dose, carrier media, salak

\section{PENDAHULUAN}

Salak (Salacca Zallaca) adalah tanaman dari keluarga palmae yang buahnya dapat dimakan. Salak merupakan salah satu buah tropis yang banyak diminati oleh masyarakat, sehingga tergolong komoditas hortikultura yang berpotensi untuk di usahakan (Ariviani dan Parnanto, 2013).

Dewasa ini terdapat fenomena, petani lebih memilih menggunakan pupuk anorganik dengan harapan agar tanaman yang diusahakan lebih cepat tumbuh dan berbuah sesuai dengan keinginan petani. Namun tanpa 
NI KADEK ARYANI. et al. Respon Pertumbuhan Bibit Salak (Salacca Zallaca) terhadap Dosis...

disadari penggunaan pupuk anorganik secara intensif dan kurang terkendali menyebabkan dampak tidak baik bagi lingkungan maupun pertanian dalam jangka panjang. Untuk menjaga agar budidaya salak tidak merusak lingkungan sekaligus mendorong agar perkebunan salak diusahakan secara organik maka diperlukan pengembangan teknologi budidaya salak ramah lingkungan, antara lain dengan menggunakan pupuk hayati fungi endomikorisa.

Fungi endomikorisa atau sering disebut Fungi Mikoriza Arbuskular (FMA) dapat ditemukan hampir pada semua ekosistem dan sangat mudah bersimbiosis dengan tanaman. Tumbuhan inangnya sebagian besar komoditi pertanian penting, seperti tanaman semusim (kacang-kacangan, padi, jagung, dan lainlain), tanaman hortikultura (buah-buahan, sayuran, dan tanaman hias), dan tanaman industri (kakao, karet, kopi, mete, dan lainlain) (Schenck dan Perez, 1990; Brundrett, 2009). Dalam bersimbiosis, endomikoriza menginfeksi bagian dalam akar tanaman inang, di dalam dan di antara sel-sel ujung akar (root tip). Infeksi endomikoriza tidak menyebabkan perubahan morfologi akar, tetapi mengubah penampilan sel dan jaringan akar. Berdasarkan sifat endomikoriza yang sebagian besar inangnya adalah tanaman pertanian, maka arah pengembangan biofertilizer dari mikoriza untuk bidang pertanian lebih banyak diarahkan pada jenis jamur tersebut (Wang dan Yong Shi, 2008; Sadhana, 2014).

Pemanfaatan FMA sebagai pupuk hayati dapat digunakan sebagai alternatif untuk menghindari kerusakan tanah akibat penggunaan pupuk anorganik secara berlebihan (Sundari et al., 2011). FMA berpotensi besar sebagai pupuk hayati karena merupakan salah satu mikroorganisme yang memiliki peranan yang sangat penting bagi tanaman, yaitu memfasilitasi tanaman dalam penyerapan hara sehingga dapat meningkatkan pertumbuhan, sebagai penghalang biologis terhadap infeksi patogen akar, meningkatkan ketersediaan air bagi tanaman dan meningkatkan hormon pemacu tumbuh (Prihastuti, 2007).

Keberhasilan pengembangan pupuk hayati endomikorisa sangat ditentukan oleh media pembawa (carrier media) bagi spora hasil isolasi, karena mikroba yang telah berhasil diisolasi memerlukan media yang cocok agar tidak sampai mati atau menurun kualitasnya (Bagyaraj dan Manjunath, 1980; Rainiyati, 2007; Sadhana, 2014). Pemilihan bahan pembawa (carrier) bagi endomikoriza sangat penting karena sangat mempengaruhi efektivitasnya sebagai biofertilizer dan kemampuannya 
memperbanyak diri setelah diinokulasikan pada tanaman inang. Pada penelitian ini media yang digunakan sebagai media pembawa bagi spora edomikorisa hasil isolasi adalah zeolit dan pasir kuarsa. Zeolit merupakan mineral yang mampu memperbaiki produktivitas tanah dan tanaman karena bersifat basa, sehingga dapat menetralkan tanah yang bersifat asam, mengurangi daya fiksasi $\mathrm{P}$ oleh koloid tanah, meningkatkan KTK, serta aktivitas mikroorganisme dalam tanah (Prafithriasari, 2010). Pasir kuarsa merupakan suatu fraksi berukuran 2,0-0,05mm dan berdasarkan sistem USDA dibedakan atas pasir yang sangat halus, halus, sedang, kasar, dan sangat kasar. Unsur hara pada pasir lebih rendah karena area permukaan pasir yang kecil per gram pasir sehingga unsur hara sedikit yang tersimpan. Namun pasir memiliki kapasitas tukar kation yang tinggi dan serasi yang lebih baik dibandingkan tanah sehingga dapat digunakan sebagai media pertumbuhan tanaman. Penelitian ini bertujuan untuk mengetahui pengaruh dosis endomikoriza dan bahan media pembawa yang diaplikasikan pada perakaran tanaman salak.

\section{BAHAN DAN METODE}

Penelitian dilakukan di Rumah Plastik, Kebun Percobaan Fakultas Pertanian Unud,
Jalan Pulau Moyo, Denpasar, dari AgustusNopember 2018. Tempat pengambilan tanah untuk isolasi endomikorisa adalah di Kecamatan Selat, Kabupaten Karangasem. Penyaringan sampel tanah dilaksanakan di Laboratorium Agronomi dan Hortikultura, pembuatan supernatant, isolasi dan identifikasi spora dilaksanakan di Laboratorium Sumber Daya Genetik dan Biologi Molekuler Unud.

Bahan yang digunakan antara lain tanah, biji salak, larutan gula, air, pasir kuarsa, zeolite, kompos, aquades, spora endomikoriza genus glomus, larutan Jonhson, pupuk urea, pupuk daun DI-growth, pupuk organik, $\mathrm{KOH}$ $10 \%, \mathrm{H}_{2} \mathrm{O}_{2} 3 \%$, HCL $1 \%$, lactogliserol, tissue, dan trypan blue. Sedangkan alat-Alat yang digunakan antara lain kantong plastik, kertas label, satu set saringan dengan

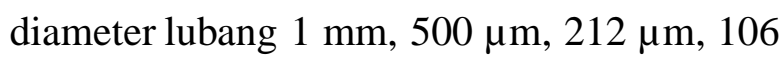
$\mu \mathrm{m}$, dan $53 \mu \mathrm{m}$, pinset, cawan petri, oven, object glass, cover glass, mikroskop stereo, mikroskop compound, timbangan, gelas beaker, sendok, tabung sentrifus, mesin sentrifus, botol semprot, pipet mikro, pipet tetes, timbangan, oven, lemari pendingin, jarum oose, polybag, kompor, panci, hand sprayer, alat tulis, dan kamera.

Penelitian menggunakan Rancangan Acak Kelompok (RAK) faktorial dengan 2 faktor perlakuan. Faktor pertama, dosis spora 
NI KADEK ARYANI. et al. Respon Pertumbuhan Bibit Salak (Salacca Zallaca) terhadap Dosis...

endomikoriza yang terdiri atas 4 taraf, yaitu : 0 spora per 500 g media pembawa sebagai kontrol (D0), 75 spora per 500 g media pembawa (D1), 150 spora per 500 g media pembawa (D2), dan 225 spora per $500 \mathrm{~g}$ media pembawa (D3). Faktor kedua, jenis media pembawa/carrier terdiri atas 2 taraf, yaitu Pasir Kuarsa (K) dan Zeolit (Z). Dengan demikian terdapat 8 perlakuan kombinasi dan masing-masing diulang sebanyak 4 kali sehingga terdapat 32 satuan percobaan.

Spora endomikorisa diisolasi dengan cara tanah sampel sebanyak $50 \mathrm{~g}$ dilarutkan dalam 1.000-1.200 ml air dan diaduk merata, selanjutnya disaring dalam satu set penyaringan dengan ukuran diameter lubang $1 \mathrm{~mm}, 500 \mu \mathrm{m}, 212 \mu \mathrm{m}, 106 \mu \mathrm{m}$, dan $53 \mu \mathrm{m}$ secara berurutan dari diameter lubang besar ke kecil. Pelarutan dan penyaringan diulang3-4 kali, kemudian sisa tanah dituang pada saringan paling atas. Saringan paling atas kemudian disemprot dengan air kran untuk memudahkan bahan saringan lolos.Setelah saringan paling atas selesai kemudian dilanjutkan saringan kedua dan seterusnya hingga saringan terakhir. Tanah yanng tersisa pada saringan 500 $\mu \mathrm{m}, \quad 212 \mu \mathrm{m}, 106 \mu \mathrm{m}$, dan $53 \mu \mathrm{m}$ dipindahkan ke tabung sentrifuse, lalu ditambahkan aquades sebanyak 25-40 $\mathrm{ml}$ dan disentrifuse dengan kecepatan 2.000 rpm selama 5 menit. Hasil sentrifuse supernatannya dibuang kemudian ditambahkan glukosa 60\%. Tabung sentrifuse ditutup rapat dan disentrifugasi kembali dengan kecepatan 2.000 rpm selama 1 menit. Setelah 1 menit, supernatan yang mengandung gula di masing- masing saringan dibilas dengan air pada saringan dengan diameter lubang $53 \mu \mathrm{m}$ dan hasil bilasan diletakan di cawan petri kemudian sporanya diisolasi dan diidentifikasi.

Spora hasil isolasi digunakan untuk membuat prototipe pupuk hayati dengan cara spora-spora yang terisolasi ditempatkan pada media pembawa dengan jumlah sesuai taraf perlakuan dosis. Media pembawa yang digunakan yaitu Zeolit dan Pasir Kuarsa, sebelum digunakan disterilisasi terlebih dulu dengan cara dikukus pada suhu $100{ }^{0} \mathrm{C}$ selama 30 menit.

Biji salak yang digunakan dalam penelitian disemai dalam media penyemaian menggunakan media pasir. Bibit hasil semaian (biji telah mengeluarkan akar dan tunas) ditanam dalam polibag volume $5 \mathrm{~kg}$. Sebelum ditanami bibit hasil semaian, setengah dari prototipe pupuk hayati $(250 \mathrm{~g})$ ditaruh pada dasar polibag, kemudia di atasnya ditaruh $3 \mathrm{~kg}$ tanah yang sudah disterilkan dengan dikukus 
pada suhu $100{ }^{0} \mathrm{C}$ selama 30 menit (kurang lebih lama pengukusan tersebut setara dengan lamanya menanak nasi). Cara penamaman bibit dalam polibag dilakukan dengan cara membuat lubang pada bagian tengah permukaan atas polibag dengan kedalaman 5$10 \mathrm{~cm}$. Bibit dicabut dengan hati-hati dari media penyemaian kemudian ditanamn pada polibag, lalu lubang disela-sela bibit diisi dengan setangah bagian lagi dari prototipe pupuk hayati ( $250 \mathrm{~g} /$ polibag). Penempatan 250 g prototipe pupuk hayati ini diatur sedemikian rupa agar betul-betul menyentuh perakaran bibit salak yang ditanam. Selanjutnya bibit dipelihara dengan baik meliputi penyiangan, penyiraman, pengendalian hama penyakit, dan pembersihan gulma secara rutin.

Pengamatan dilakukan pada umur 2 dan 4 bulan setelah tanam (BST), dengan cara mendesktruksi/membongkar bibit dari polibag secara hati-hati. Variabel yang diamati meliputi tinggi tanaman, diameter batang, jumlah daun, khlorofil daun, luas daun, jumlah akar, panjang akar, berat kering tajuk, berat kering akar, berat kering total, infeksi akar oleh mikorisa, dan kandungan $\mathrm{P}$ bibit.

Data hasil pengamatana dianalisis menggunakan analisis sidik ragam (Anova) sesuai rancangan yang digunakan. Apabila analisis sidik ragam berpengarauh nyata, maka dilakukan dengan Uji BNT taraf $5 \%$.

\section{HASIL DAN PEMBAHASAN}

Hasil analisis statistika menunjukkan interaksi antara dosis spora endomikorisa dan media pembawa berpengaruh tidak nyata terhadap semua variabel yang diamati. Pada perlakuan faktor tunggal, dosis spora endomikorisa berpengaruh nyata hanya terhadap infeksi akar oleh mikorisa umur 2 dan 4 BST, sedangkan media pembawa berpengaruh nyata hanya terhadap tinggi tanaman umur 2 BST, luas daun umur 2 BST, berat segar tajuk umur 2 BST, berat segar total umur 2 BST, berat kering tajuk umur 2 BST, berat kering akar umur 2 BST, berat kering total umur 2 BST, infeksi akar umur 2 dan 4 BST, dan kandungan P daun umur 4 BST.

Pemberian spora endomikorisa dosis $0,75,150$ dan 225 spora per polibag pengaruhnya berbeda tidak nyata terhadap tinggi bibit, luas daun, berat kering tajuk dan berat kering akar bibit pada umur 2 dan 4 BST, sedangkan terhadap jumlah daun, dosis 150 dan 225 spora per polibag memberikan nilai nyata lebih tinggi dibandingkan dosis 0 dan 75 spora per polibag (Tabel 1). Data tersebut menunjukkan bahwa walaupun jumlah daun pada dosis 150 dan 250 spora per polibag meningkat, tetapi tidak mempengaruhi tinggi 
NI KADEK ARYANI. et al. Respon Pertumbuhan Bibit Salak (Salacca Zallaca) terhadap Dosis...

dan berat kering bibit. Hal tersebut tercermin dari berat kering total bibit pada umur 2 dan 4 BST berbeda tidak nyata antara dosis 0 , 75, 150 dan 225 spora per polibag. Hasil pernelitian ini sesuai dengan hasil penelitian Rusdi et al. (2011) bahwa banyaknya jumlah mikoriza yang diberikan ke tanaman tidak secara langsung membuat tanaman tumbuh lebih baik. Astutik (2010) juga menyatakan bahwa pemberian mikoriza tidak berpengaruh terhadap tinggi tanaman dan panjang akar. Sedangkan menurut Hernadi et al. (2012), manfaat penambahan cendawan mikoriza yaitu, pertumbuhan tanaman menjadi lebih baik sehingga hasil yang didapat jauh lebih banyak.

Pemberian endomikoriza dosis 75, 150 dan 225 spora per polibag meningkatkan secara nyata infeksi akar dibandingkan kontrol (tanpa dosis spora endomikorisa). Pada dosis 75, 150 dan 225 spora, infeksi akar oleh endomikorisa berturut-turut $71,25 \%, 68,75 \%$ dan $78,75 \%$ sedangkan pada kontrol hanya 26,25\% (Tabel 2). Lebih tingginya infeksi akar pada pemberian spora endomikorisa menunjukkan bahwa simbiosis antara bibit salak dengan mikorisa meningkat dengan pemberian endomikorisa. Peningkatan simbiosis tersebut menyebabkan penyerapan hara $\mathrm{P}$ oleh tanaman meningkat, ditunjukkan oleh lebih tingginya kandungan hara $\mathrm{P}$ daun pada pemberian endomikorisa. Pada dosis D2 dan D3 kandungan hara P daun masing-masing $0,58 \%$ dan $0,40 \%$, nyata lebih tinggi dibandingkan pada pada D0 dan D1 dengan nilai masingmaisng 0,36\% dan 0,37\%. Menurut Brundret (2009), mikoriza merupakan jamur yang hidup berdasarkan hubungan simbiosis mutualisme dengan perakaran tanaman tingkat tinggi. Menurut Zasvari et al. (2012), tanaman inang memperoleh hara dari mikoriza sedangkan mikoriza memperoleh karbohidrat atau bahan makanan dari tanaman inang. Harahap et al. (2014) juga menyatakan bahwa dengan pengaplikasian $10 \mathrm{~g}$ mikoriza per bibit tanaman sawit menghasilkan derajat infeksi tertinggi. Menurut Mosse (1981) proses infeksi mikoriza dipengaruhi oleh faktor kepekaan inang, iklim, dan kondisi tanah. Brundrett (2009) juga menyatakan bahwa faktor lingkungan terutama intesitas cahaya sangat berpengaruh terhadap pertumbuhan dan perkembangan mikoriza serta keberhasilan simbiosisnya dengan inang. Intesitas cahaya matahari tinggi akan mempengaruhi kapasitas dan derajat infeksi mikoriza pada tanaman. 
Tabel 1. Pengaruh media pembawa dan dosis spora endomikorisa terhadap tinggi tanaman, jumlah daun, luas daun, berat kering tajuk dan akar bibit salak umur 2BST dan 4 BST

\begin{tabular}{|c|c|c|c|c|c|c|c|c|c|c|}
\hline \multirow{2}{*}{ Perlakuan } & \multicolumn{2}{|c|}{ Tinggi Tanaman } & \multicolumn{2}{|c|}{ Jumlah Daun } & \multicolumn{2}{|c|}{ Luas Daun } & \multicolumn{2}{|c|}{ Berat kering Tajuk } & \multicolumn{2}{|c|}{ Berat kering akar } \\
\hline & $2 \mathrm{BST}$ & 4BST & $2 \mathrm{BST}$ & 4BST & 2 BST & $4 \mathrm{BST}$ & $2 \mathrm{BST}$ & 4BST & $2 \mathrm{BST}$ & $4 \mathrm{BST}$ \\
\hline \multicolumn{11}{|c|}{ Dosis Spora Mikoriza } \\
\hline $\mathrm{D}_{0}$ & $23.19 a$ & $23.50 \mathrm{a}$ & $2.88 \mathrm{a}$ & $3.38 \mathrm{~b}$ & $111.03 \mathrm{a}$ & $106.05 a$ & $1.21 \mathrm{a}$ & $4.85 \mathrm{a}$ & $1.01 \mathrm{a}$ & $1.05 \mathrm{a}$ \\
\hline $\mathrm{D}_{1}$ & $22.38 \mathrm{a}$ & $21.50 \mathrm{a}$ & $2.88 \mathrm{a}$ & $3.17 \mathrm{~b}$ & $112.07 \mathrm{a}$ & $111.34 \mathrm{a}$ & $1.42 \mathrm{a}$ & $4.03 a$ & $0.86 a$ & $1.25 \mathrm{a}$ \\
\hline $\mathrm{D}_{2}$ & $21.94 a$ & $21.50 \mathrm{a}$ & $3.13 \mathrm{a}$ & $4.00 \mathrm{a}$ & $125.26 \mathrm{a}$ & $123.81 \mathrm{a}$ & $1.31 \mathrm{a}$ & $4.60 \mathrm{a}$ & $1.08 \mathrm{a}$ & $1.04 \mathrm{a}$ \\
\hline $\mathrm{D}_{3}$ & $20.81 \mathrm{a}$ & $23.00 \mathrm{a}$ & $3.00 \mathrm{a}$ & $3.50 \mathrm{a}$ & $113.95 \mathrm{a}$ & $123.96 \mathrm{a}$ & $1.18 \mathrm{a}$ & $5.39 a$ & $1.07 \mathrm{a}$ & $1.11 \mathrm{a}$ \\
\hline BNT 5\% & 2.52 & 2.85 & 0.31 & 0.59 & 19.41 & 21.83 & 0.64 & 1.42 & 0.25 & 0.4 \\
\hline \multicolumn{11}{|c|}{ Media Pembawa } \\
\hline $\mathrm{M}_{\mathrm{Z}}$ & $23.31 \mathrm{a}$ & $22.06 \mathrm{a}$ & $2.94 a$ & $3.25 a$ & $126.06 \mathrm{a}$ & $111.25 \mathrm{a}$ & $3.49 a$ & $4.44 a$ & $1.14 \mathrm{a}$ & $1.11 \mathrm{a}$ \\
\hline $\mathrm{M}_{\mathrm{K}}$ & $20.84 b$ & $22.69 \mathrm{a}$ & $3.00 \mathrm{a}$ & $3.77 \mathrm{~b}$ & $56.03 b$ & $12133 a$ & $2.56 \mathrm{~b}$ & $4.99 a$ & $0.87 b$ & $1.11 \mathrm{a}$ \\
\hline BNT $5 \%$ & 1.78 & 2.02 & 0.22 & 0.41 & 13.72 & 15.44 & 0.45 & 1 & 0.18 & 0.29 \\
\hline
\end{tabular}

Keterangan: angka yang diikuti huruf yang berbeda pada perlakuan dan kolom yang sama menunjukkan berbeda nyata pada uji beda nyata terkecil (BNT) taraf 5\%.

Walaupun infeksi akar oleh mikorisa meningkat dan kandungan hara $\mathrm{P}$ daun lebih tinggi pada perlakuan yang mendapat mikorisa, tetapi pertumbuhan bibit salak yang dicerminkan dari berat kering oven total bibit berbeda tidak nyata dengan kontrol. Pertumbuhan tajuk dan akar juga berbeda tidak nyata, yang dicerminkan oleh berat kering tajuk dan berat kering akar berbeda tidak nyata dengan kontrol. Menurut Musfal (2010), berat kering oven tanaman mencerminkan pertumbuhan tanaman dan panjang daun, dan lebar daun. banyaknya unsur hara yang terserap per satuan bobot biomasa yang dihasilkan. Hasil penelitian ini berbeda dengan yang didapatkan oleh Prasasti et al. (2013) bahwa perlakuan dosis mikoriza $50 \mathrm{~g}$ berpengaruh nyata terhadap pertumbuhan kacang tanah, baik pada tinggi maupun berat kering tanaman. Rusdi et al. (2011) juga menyatakan bahwa inokulasi mikoriza 7,5 g per tanaman mampu menghasilkan laju pertumbuhan vegetatif tertinggi untuk parameter tinggi tanaman, 
NI KADEK ARYANI. et al. Respon Pertumbuhan Bibit Salak (Salacca Zallaca) terhadap Dosis...

Tabel 2. Pengaruh media pembawa dan dosis spora endomikorisa terhadap berat kering total bibit, infeksi akar, kandungan $\mathrm{P}$ daun, klorofil daun, panjang akar dan jumlah akar bibit umut 2BST dan 4 BST

\begin{tabular}{|c|c|c|c|c|c|c|c|c|c|}
\hline \multirow{2}{*}{ Perlakuan } & \multicolumn{2}{|c|}{ Berat Kering Total } & \multicolumn{2}{|c|}{ Infeksi akar } & \multirow{2}{*}{$\begin{array}{c}\text { Kandungan P daun } \\
\text { 4BST }\end{array}$} & \multicolumn{2}{|c|}{ Klorofil daun } & \multirow{2}{*}{$\begin{array}{c}\text { Panjang akar } \\
\text { 4BST }\end{array}$} & \multirow{2}{*}{$\begin{array}{c}\begin{array}{c}\text { Jumlah } \\
\text { akar }\end{array} \\
\text { 4BST }\end{array}$} \\
\hline & $2 \mathrm{BST}$ & 4BST & $2 \mathrm{BST}$ & 4BST & & $2 \mathrm{BST}$ & 4BST & & \\
\hline \multicolumn{10}{|c|}{ Dosis spora Mikoriza } \\
\hline $\mathrm{D}_{0}$ & $4.17 \mathrm{a}$ & $5.80 \mathrm{a}$ & $25.00 \mathrm{c}$ & $26.25 \mathrm{c}$ & $0.36 \mathrm{~b}$ & $44.72 \mathrm{a}$ & $42.57 \mathrm{a}$ & $31.63 \mathrm{a}$ & $82.88 \mathrm{a}$ \\
\hline$D_{1}$ & $3.78 \mathrm{a}$ & $5.28 \mathrm{a}$ & $65.00 \mathrm{~b}$ & $71.25 \mathrm{a}$ & $0.37 \mathrm{~b}$ & $43.03 \mathrm{a}$ & $39.39 a$ & $32.25 \mathrm{a}$ & $81.93 \mathrm{a}$ \\
\hline $\mathrm{D}_{2}$ & $4.28 \mathrm{a}$ & $5.63 \mathrm{a}$ & $75.00 \mathrm{ab}$ & $68.75 b$ & $0.58 \mathrm{a}$ & $40.41 \mathrm{a}$ & $35.63 a$ & $32.88 \mathrm{a}$ & $95.38 \mathrm{a}$ \\
\hline$D_{3}$ & $3.88 \mathrm{a}$ & $6.50 \mathrm{a}$ & $81.25 \mathrm{a}$ & $78.75 . \mathrm{a}$ & $0.40 \mathrm{~b}$ & $41.96 \mathrm{a}$ & $37.44 \mathrm{a}$ & $31.88 \mathrm{a}$ & $92.38 \mathrm{a}$ \\
\hline BNT $5 \%$ & 0.82 & 1.68 & 11.04 & 9.69 & 0.15 & 5.77 & 9.81 & 11.25 & 53.48 \\
\hline \multicolumn{10}{|c|}{ Media Pembawa } \\
\hline $\mathrm{Mz}$ & $4.63 a$ & $5.55 \mathrm{a}$ & $56.88 \mathrm{a}$ & $66.25 \mathrm{a}$ & $0.421 \mathrm{a}$ & $42.29 \mathrm{a}$ & $41.25 \mathrm{a}$ & $33.27 \mathrm{a}$ & $86.50 \mathrm{a}$ \\
\hline $\mathrm{M}_{K}$ & $3.42 \mathrm{~b}$ & $6.10 \mathrm{a}$ & $50.25 \mathrm{~b}$ & $56.25 b$ & $0.434 \mathrm{a}$ & $42.77 \mathrm{a}$ & $36.27 \mathrm{a}$ & $31.09 \mathrm{a}$ & $89.78 \mathrm{a}$ \\
\hline BNT $5 \%$ & 0.58 & 1.19 & 7.8 & 6.85 & 0.11 & 4.08 & 6.93 & 7.96 & 37.82 \\
\hline
\end{tabular}

Keterangan: angka yang diikuti huruf yang berbeda pada perlakuan dan kolom yang sama menunjukkan berbeda nyata pada uji beda nyata terkecil (BNT) taraf $5 \%$.

Media pembawa zeolite memberikan tinggi bibit dan luas daun pada umur 2 BST nyata lebih tinggi dibandingkan dengan pasir kuarsa (Tabel 1). Perlakuan media pembawa zeolite juga memberikan nilai yang lebih baik untuk variabel berat segar tajuk pada pengamatan umur 2 BST $(13,56 \mathrm{~g})$, berat segar total pada pengamatan umur 2 BST $(18,64 \mathrm{~g})$, berat kering tajuk pada pengamatan umur 2 BST $(3,49 \mathrm{~g})$, berat kering akar pada pengamatan umur 2 BST $(1,14 \mathrm{~g})$, dan berat kering total pada pengamatan umur 2 BST (4,63 g) Berdasarkan data hasil penelitian ini, media pembawa zeolite lebih baik digunakan sebagai media pembawa spora endomikorisa dibandingkan pasir kuarsa. Menurut Bertham (2003), zeolit merupakan media yang baik digunakan sebagai bahan pembawa karena bersifat stabil dan tidak mudah berubah atau rusak karena siraman air.

Media pembawa zeolit menyebabkan terjadinya infeksi akar oleh mikorisa lebih tinggi dibandingkan dengan media pembawa pasir kuarsa. Pada Tabel 2 dapat dilihat, pada pengamatan umur 2 BST infeksi akar pada media pembwa zeolit sebesar $56,88 \%$ sedangkan pada umur 4 BST 66,25\%, nyata lebih tinggi dibandingkan infeksi akar pada media pembwa pasir kuarsa dengan nilai pada 2 dan 4 BSt masing-masing 50,25\% dan $56,25 \%$. Lebih tingginya infeksi akar oleh 
mikorisa pada media pembawa zeolit menunjukkan bahwa simbiosis antara mikorisa dengan bibit salak lebih baik pada madia pembawa zeolit. Zeolit merupakan adsorbent yang unik, karena memiliki ukuran pori yang sangat kecil dan seragam. Zeolit hanya mampu menyerap molekulmolekul yang berdiameter sama atau lebih kecil dari diameter celah rongga, sedangkan molekul yang diameternya lebih besar dari pori zeolit akan tertahan dan hanya melintasi antar partikel. Zeolit yang telah dipanaskan dapat berfungsi sebagai penyerap gas atau cairan (Khairinal dan Trisunaryanti, 2000).

Walaupun infeksi akar pada media pembawa zeolit lebih tinggi dibandingkan pada media pasir kuarsa, tetapi kandungan hara $\mathrm{P}$, klorofil daun, panjang akar dan jumlah akar berbeda tidak nyata. Hal tersebut menyebabkan berat kering oven total bibit pada umur 4 BST berbeda tidak nyata. Hasil ini berbeda dengan pernyataan Deptan (2001) bahwa zeolit merupakan mineral yang mampu memperbaiki produktivitas tanah dan tanaman karena bersifat basa, sehingga dapat menetralkan tanah yang bersifat asam, mengurangi daya fiksasi $\mathrm{P}$, dan meningkatkan KTK serta aktivitas mikroorganisme dalam tanah.

\section{SIMPULAN}

Interaksi antara dosis spora endomikoriza dengan media pembawa berpengaruh tidak nyata terhadap pertumbuhan bibit salak. Pemberian spora endomikorisa dosis 75, 150 dan 225 spora per polibag men ingkatkan infeksi akar dan kandungan hara $\mathrm{P}$ daun dibandingkan kotrol, tetapi tinggi bibit, luas daun, berat kering tajuk, berat kering dan berat kering total bibit berbeda tidak nyata. Media pembawa zeolit menyebabkan infeksi akar oleh mikorisa lebih tinnggi dibandingkan media pasir kuarsa, tetapi serapan hara $\mathrm{P}$ dan pertumbuhan bibit berbeda tidak nyata. Berdasarkan hasil penelitian ini perlu dilakukan pengamatan lebih panjang dari pengaruh dosis spora endomikorisa dan media pembawa terhadap pertumbuhan bibit salak.

\section{DAFTAR PUSTAKA}

Ariviani, S., N.H.R. Parnanto. 2013. Kapasitas antioksidan buah salak (Salacca edulis) kultivar pondoh, nglumut dan Bali serta korelasinya dengan kadar fenolik total dan vitamin C. Jurnal ilmu-ilmu pertanian Indonesia 9:11-16.

Astutik, T.Y. 2010. Uji Infektivitas dan Efektivitas Mikoriza dengan Berbagai Macam Pestisida dengan Indikator Tanaman Cabai Merah (Capsicum annuum L.)

Bagyaraj, D.J., A. Manjunath. 1980. Selection of a Suitable Host for Mass Production of Arbuscular Mycorrhizal 
NI KADEK ARYANI. et al. Respon Pertumbuhan Bibit Salak (Salacca Zallaca) terhadap Dosis...

Inoculan. Plant and soil 55(2): 495498.

Bertham. 2003. Teknik pemurnian biakan monoxonic CMA dengan metode cawan petri dan tabung reaksi. Jurnal ilmu-ilmu pertanian Indonesia 5:18-26.

Brundrett, M. 2009. Mycorrhizal Associations and other Means of Nutrition of Vascular Plants: Understanding the Global Diversity of Host Plants by Resolving Conflicting Information and Developing Reliable Means of Diagnosis. Plant and Soil 320:37-77

Departemen Pertanian. 2001. Zeolit untuk Pertanian. Lembar Informasi Pertanian No. 15 Seri :Tanaman Pangan/2001/djs Agdex : 530. Jawa Barat, Bandung

Harahap, R.A., C. Suherman, S. Rosniawaty. 2014. Pemanfaatan fungi mikoriza arbuskular pada media campuran subsoil dan kompos kulit pisang terhadap pertumbuhan kelapa sawit (Elaeis gueneensis Jacq) varietas PPKS 540 di pembibitan awal. Agric.sci. 1 (4): $244-253$.

Hernadi, P., Z. Sasvari, J. Albrechtova, M. Vosatka, K. Posta. 2012. Arbuscular Mycorrhizal Inoculants Increase Yield of Spice Pepper and Affects Indigenous Fungal Commu- nity in the Field. Hort Science 47(5): 603-606.

Khairinal, W. Trisunaryanti. 2000. Dealuminasi Zeolit Alam Wonosari dengan Perlakuan asam dan Proses Hidrotermal. Prosiding Seminar Nasional Kimia VIII. Yogyakarta.

Mosse, S. 1981. Vesicular arbuscular mycoriza research for tropical agriculture. ResearchBulletin.

Musfal. 2010. Potensi Cendawan Mikoriza Arbuskula untuk Meningkatkan Hasil Tanaman Jagung. Jurnal Litbang Pertanian 29 (4): 154-158.

Prafithriasari, M., Nurbaity, A. 2010. Infektivitas inokulan Glomus sp. dan
Gigaspora sp. pada berbagai komposisi media zeolit-arang sekam dan pengaruhnya terhadap pertumbuhan Sorgum (Sorghum bicolor). Jurnal agrikultura. 21 (1): 39-45

Prasasti, O.H., K.I Purwani, S. Nurhatika. 2013. Pengaruh mikoriza Glomus fasciculatumterhadap pertumbuhan vegetatif tanaman Kacang Tanah yang terinfeksi patogen Sclerotium rolfsii. J. Sains dan Seni Pomits 2 (2) :74-78.

Prihastuti. 2007. Isolasi dan karakterisasi mikoriza vesikular-arbuskular di lahan kering masam, Lampung Tengah. Berk. Penel. Hayati: 12 (99-106).

Rainiyati. 2007. Status dan Keanekaragaman Cendawan Mikoriza Arbuskula (CMA) Pisang Raja Nangka dan Potensi Pemanfaatannya untuk Peningkatan Produksi Pisang Asal Kultur Jaringan di Kabupaten Merangin, Jambi. Disertasi. Sekolah Pascasarjana IPB, Bogor. 140p

Rusdi, S. Suharsono, E.D. Mustikarini. 2011. Pengaruh Pemberian Mikoriza Terhadap Pertumbuhan Nenas Bogor (Lokal Bangka ) di PMK Bangka.

Sadhana, B. 2014. Arbuscular Mycorrhizal Fungi (AMF) as a Biofertilizer: a Review. International Journal of Current Microbiology Applied Science 3(4): 384-400.

Sasvari, Z. F. Magurno1, D. Galanics, T. T. Nhu Hang, T. T. Hong Ha, N. D. Luyen, L. M. Huong, K. Posta. 2012. Isolation and Identification of Arbuscular Mycorrhizal Fungi from Agricultural Fields of Vietnam. American Journal of Plant Sciences 3:1796-1801

Schenck, N.C., Y. Perez. 1990. Manual for the Identification of V. A. Mycorrhizal (VAM) Fungi. University of Florida Press, Florida, USA. 241p. 
Sundari, S., T. Nurhindayati, I. Trisnawati. 2011. Isolasi dan Identifikasi Mikoriza Indigenous dari Perakaran Tembakau Sawah (Nicotiana tabacum L) di Area Persawahan Kabupaten Madura. Fakultas matematika dan Ilmu Pengetahuan Alam, Institut Teknologi Sepuluh November.

Wang, F.Y., Z. Yong Shi. 2008. Biodiversity of Arbuscular Mycorrhizal Fungi in China: a Review. Advances in Environmental Biology 2(1): 31-39. 